\title{
Hepatoprotective Effects of Coriandrum Sativum Essential Oil Against Acute Hepatotoxicity Induced by Carbon Tetrachloride on Rats
}

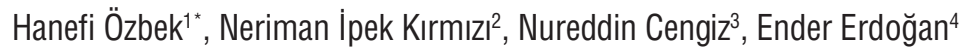

\author{
${ }^{1}$ Istanbul Medipol University, School of Medicine, Department of Pharmacology, Istanbul \\ ${ }^{2}$ Istanbul Medipol University, Vocational School of Health Services, Istanbul \\ ${ }^{3}$ Sakarya University, Faculty of Medicine, Department of Histology-Embriology, Sakarya \\ ${ }^{4}$ Selçuk University, Faculty of Medicine, Department of Histology-Embriology, Konya
}

\begin{abstract}
The aim of this study was to evaluate effect of Coriandrum sativum (CS) essential oil in rat model of carbon tetrachloride $\left(\mathrm{CCl}_{4}\right)$ induced liver toxicity. Experimental groups were formed as follows: isotonic saline solution (ISS), silibinin, CS-1 (o,3ml/ $\mathrm{kg}), \mathrm{CS}-2$ (o,6 ml/kg). Agents were administered intraperitoneally. Blood and liver tissues were collected at the end of the study ended. Aspartate aminotransferase (AST) and alanine aminotransferase (ALT) levels were measured. Liver tissues were evaluated histopathologically. One-way analysis of variance (ANOVA) was used for statistical analyses.As a result silibinin and CS-2 decreased blood AST and ALT levels of their groups and these biochemical results were supported by histopathological results. In conclusion this study has provided evidence that Coriandrum sativum essential oil has significant hepatoprotective effect on carbon tetrachloride induced liver toxicity in rats.
\end{abstract}

Keywords: Coriandrum sativum, hepatoprotective activity, carbon tetrachloride, rats, essential oil.

\section{INTRODUCTION}

Taking advantage of plants to treat diseases is becoming a popular and widespread topic. Also in Turkey, studying pharmacological and toxicological activity of plants is an increasing trend. Although Turkey has limited economic resources and drug production facilities through the synthesis could not come to an adequate level, it has a wide flora. It would be a rational approach for countries like Turkey to use natural sources for medicine development and encourage the society to utilize them ${ }^{1}$.

*Corresponding author: Hanefi Özbek

E-mail address: hozbek@medipol.edu.tr 
Coriandrum sativum L. (CS) (kişniş, aşuti) belongs to Apiaceace (Umbelliferae) family ${ }^{2,3}$. It is a herbaceous plant which grows annually and has a 20-60 $\mathrm{cm}$ height. Spice of CS contains volatile oil, tanin, resin and sugar. The volatile oil is colorless liquid with light-yellow color which is obtained by water vapor distillation with $0.3-0.4 \%$ yield. Major ingredients of the volatile oil are: $60-70 \%$ linalool, $6 \%$-terpinen, $\alpha$-pinene, camphor, geraniol, p-cymene, geranyl acetate, limonene, aldehydes, esters and alcohols. It is useful in food industry as spice, tincture and alcoholic/non-alcoholic beverages beside this perfumery and cosmetics industries use CS too ${ }^{3}$. It helps flatulence and indigestion ${ }^{2}$. In Turkish folk medicine, it is reported to be used as hepatoprotective and analgesic (head and tooth ache). Additionally the usage of this genus plants against dizziness, pharyngitis, glossitis, urinary tract infections, hemorrhoids, dysentery, urticaria and apht have been recorded ${ }^{4}$.

According to literature CS is a very effective anxiolytic in mice ${ }^{5}$, has antibacterial effect against Escherichia coli, Bacillus megaterium and Salmonella choleraesuis $^{6,7}$, can reduce cholesterol and triglyceride levels in rats ${ }^{8}$. In addition CS has a potent antioxidant activity (more potent than ascorbic acid) ${ }^{9}$, effective in the treatment of inflammatory bowel disease ${ }^{10}$, has insulin-like activity in streptozotocin-induced diabetic rat model ${ }^{11}$. Lastly CS can cause abortus in pregnant rats related with the significant decrease in the progesterone levels in the 5 th day of the pregnancy ${ }^{12}$.

There is not sufficient data about hepatoprotective activity of CS in the literature. In current study CS was investigated for the potential hepatoprotective activities on carbon tetrachloride induced liver toxicity in rats.

\section{METHODOLOGY}

\section{Plant materials}

Coriandrum sativum L., was collected from different parts of Turkey. The taxonomic identification of the plants was confirmed by a botanist. Voucher specimens are kept in the laboratory (sample number: B-17). Seeds of the plant were boiled in the Clevenger apparatus. Essential oil which was collected from apparatus was stored in the laboratory tubes. Yield of the essential oil was $0.2 \%$.

\section{Chemicals}

Carbon tetrachloride $\left(\mathrm{CCl}_{4}\right)$ obtained from Merck KgA (Darmstadt-Germany) and silibinin was provided from Sigma (Steinheim, Germany). $\mathrm{CCl}_{4}$ was dissolved in the olive oil (v/v, 1:1) which was obtained from Fluka (Steinheim-Germany). 


\section{Animals}

Male and female Sprague-Dawley rats (200-300 g) were used in this experiment and they were obtained from the Animal House. The animals were housed in standard plastic cages at room temperature $\left(22 \pm 2{ }^{\circ} \mathrm{C}\right)$, with artificial light from 7.00 am to $7.00 \mathrm{pm}$, and provided with pelleted food and water ad libitum. The study protocol was approved by the Ethical Committee.

\section{Hepatoprotective activity assay}

Animal groups were designed as follow $(n=6)$ : Control group 1 received isotonic saline solution (ISS) $0.2 \mathrm{~mL}$, Group 2 received $\mathrm{CCl}_{4}(0.8 \mathrm{~mL} / \mathrm{kg})$, Group 3 received silibinin $(50 \mathrm{mg} / \mathrm{kg})+\mathrm{CCl}_{4}(0.8 \mathrm{ml} / \mathrm{kg})$, Group 4 received $\mathrm{CS}-1$ ( 0.3 $\mathrm{ml} / \mathrm{kg})+\mathrm{CCl}_{4}(0.8 \mathrm{~mL} / \mathrm{kg})$, Group 5 received CS-2 $(0.6 \mathrm{ml} / \mathrm{kg})+\mathrm{CCl}_{4}(0.8 \mathrm{ml} / \mathrm{kg})$ i.p. daily for seven days. Doses of CS were determined according to the study of Ozbek et al. ${ }^{13}$. Blood and liver samples were collected after seven days treatment and the serum was used for the assay of the marker enzymes aspartate aminotransferase (AST) and alanine aminotransferase (ALT).

\section{Histopathological examination of the liver}

The livers of the experimental animals were extracted after scarifying the animals and fixed in $10 \%$ neutral buffered-formalin prior to routine processing in paraffin-embedded blocks. Sections ( $4 \mu \mathrm{m}$ thick) were cut and stained using Hematoxylin-eosin (HE). Histological damage was expressed using the following score system; o:absent; +:mild; ++:moderate; +++ : severe $^{14}$.

\section{Statistical Analyses}

Results are reported as mean $\pm \mathrm{SEM}$ (standard error of mean). One-way analysis of variance (One-way ANOVA; post-hoc Dunnett t ad LSD) was used for statistical analyses. Probability levels of less than $0.05(\mathrm{P}<0.05)$ were considered significant.

\section{RESULTS AND DISCUSSION}

Plasma AST and ALT levels of the groups were given in Table 1.

Histopathological examination results were exhibited in Table 2, Figure 1 and Figure 2.

This study provided evidence that CS essential oil has significant hepatoprotective effect on $\mathrm{CCl}_{4}$ induced liver toxicity in rats.

According to the Kumar et al. water-extract of CS leafs has hepatoprotective activity in mice model of profenofos induced liver toxicity ${ }^{15}$. Furthermore, in a study which was conducted by Pandey et al. ethanol extract of CS provided protective activity against carbon tetrachloride induced liver toxicity on rats ${ }^{16}$. Results of 
these studies which were performed with different CS extracts supported our study which was conducted with CS essential oil. Beside these, Cioanca et al. stated that CS essential oil has antioxidant activity ${ }^{17}$. Hence, hepatoprotective activities can be related with the antioxidant properties of CS.

According to Samojlik et al. oral administration $(0.03 \mathrm{~g} / \mathrm{kg})$ of CS essential oil to mice with $\mathrm{CCl}_{4}$ induced liver toxicity did not produce hepatoprotective activity ${ }^{18}$. This result is in conflict with our findings and the findings of other studies mentioned above. This dilemma may be related with the species of the animals (Samojlik et al. used mice whereas we used rat). Samojlik et al. only administered a single dose which was $0.03 \mathrm{~g} / \mathrm{kg}$ CS which may be inadequate for the activity. In accordance with this view, in our study although hepatoprotective activity in 0.3 $\mathrm{mL} / \mathrm{kg}$ was not significant, the effective dose was $0.6 \mathrm{~mL} / \mathrm{kg}$. Additionally Samojlik et al. administered CS extract not intaperitoneally which may also change the results. Since, in oral route CS extract may be changed chemically in gastric acid, and also elimination in liver after duodenal absorption may be possible. However pharmacokinetics in i.p. is similar to i.v. route since there is no gastrointestinal absorption period and first pass effect.

Linalool, $\gamma$-terpinen, $\alpha$-pinene, camphor, geraniol, p-cymene, geranyl acetate are reported as the major molecules of CS essential oil. Hepatoprotective effect of CS can be related with one or more molecules that are mentioned above. In further studies, all chemical molecules that are mentioned above should be studied separately to detect the molecule(s) which is/are responsible from the hepatoprotective effect.

Table 1: Effects of CS essential oil on serum levels of AST and ALT.

\begin{tabular}{|l|c|c|c|c|}
\hline \multirow{2}{*}{ Uygulama } & \multicolumn{2}{|c|}{ ALT } & \multicolumn{2}{c|}{ AST } \\
\cline { 2 - 5 } & Serum (U/L) & $\mathbf{9 5} \% \mathbf{~ C l}$ & Serum (U/L) & $\mathbf{9 5} \% \mathbf{~ C l}$ \\
\hline Control (ISS) & $48.8 \pm 2.9$ & $41.43-56.24$ & $164.5 \pm 10.8$ & $136.67-192.33$ \\
\hline CCI $_{4}$ & a $1068.3 \pm 55.3$ & $937.40-1199.10$ & a $1682.6 \pm 96.1$ & $1455.29-1909.97$ \\
\hline Silibinin & ab $406.5 \pm 56.5$ & $261.21-551.79$ & ab $732.0 \pm 64.8$ & $565.57-898.43$ \\
\hline CS-1 (0.3 mL/kg) & a $992.2 \pm 294.4$ & $235.32-1749.91$ & a $1619.7 \pm 456.8$ & $445.43-2793.91$ \\
\hline CS-2 (0.6 mL/kg) & ab $663.0 \pm 84.0$ & $429.85-896.15$ & ab $765.0 \pm 58.4$ & $602.93-927.07$ \\
\hline \multicolumn{1}{|c|}{ F/p } & $9.983 / 0.001$ & \multicolumn{3}{c|}{$10.125 / 0.001$} \\
\hline
\end{tabular}

a: $\mathrm{p}<0.05$ compared to control (ISS)

b: $\mathrm{p}<0.05$ compared to $\mathrm{CCl}_{4}$ 
Table 2: Histopathological changes in the liver of rats.

\begin{tabular}{|c|c|c|c|c|}
\hline \multirow[b]{2}{*}{ Groups } & \multicolumn{4}{|c|}{ Microscopic Observation } \\
\hline & $\begin{array}{c}\text { Ballooning } \\
\text { degenerations and } \\
\text { steatosis }\end{array}$ & $\begin{array}{l}\text { Apoptosis and/ } \\
\text { or necrosis }\end{array}$ & $\begin{array}{l}\text { Bridging } \\
\text { necrosis }\end{array}$ & $\begin{array}{l}\text { Average } \\
\text { score }^{*}\end{array}$ \\
\hline Control (ISS) & 0 & 0 & 0 & $0 / 6=0.00$ \\
\hline $\mathrm{CCl}_{4}$ & 15 & 14 & 13 & $42 / 6=7.00$ \\
\hline Silibinin & 7 & 8 & 4 & $19 / 6=3.17$ \\
\hline CS-1 & 12 & 12 & 10 & $34 / 6=5.67$ \\
\hline CS-2 & 10 & 9 & 7 & $26 / 6=4.33$ \\
\hline
\end{tabular}

* Average score $=$ Total score $/ \mathrm{n}$

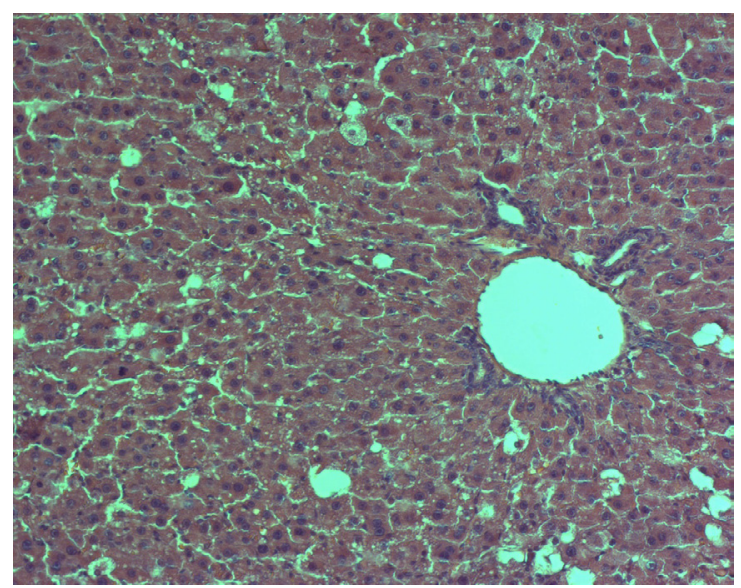

Figure 1: CS-1 $0.3 \mathrm{~mL} / \mathrm{kg}(\mathrm{HE} \times 20)$

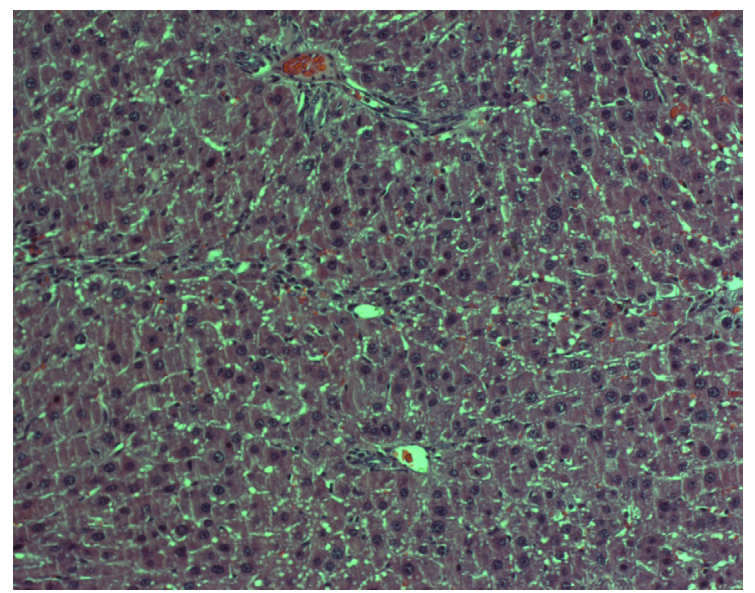

Figure 2: CS-2 $0.6 \mathrm{~mL} / \mathrm{kg}(\mathrm{HE} \times 20)$ 


\section{REFERENCES}

1. Kayaalp, S.O. [Principles of Clinical Pharmacology and Basic Regulations], 5th ed.; Pelikan Yayincilik: Ankara, 2013.

2. Baytop, T. Therapy with Medicinal Plants in Turkey, 2nd ed.; Nobel Tip Kitabevleri: Istanbul, 1999; pp:272.

3. Akgül, A. [Science of Spice and Technology], 1st ed.; Gida Teknolojisi Dernegi Yayinlari: Ankara, 1993; pp: 113-114.

4. Pamuk, A. [The Encyclopedia of Medicinal Plants], Pamuk Yayincilik ve Matbaacilik: Istanbul, 1998; pp: 656.

5. Emamghoreishi, M.; Khasaki, M.; Aazam, M.F. Coriandrum sativum: evaluation of its anxiolytic effect in the elevated plus-maze. J. Ethnopharmacol. 2005, 96, 365-370.

6. Lo Cantore, P.; Iacobellis, N.S.; De Marco, A.; Capasso, F.; Senatore, F. Antibacterial activity of Coriandrum sativum L. and Foeniculum vulgare Miller Var. vulgare (Miller) essential oils. J. Agric. Food Chem. 2004, 52, 7862-7866.

7. Kubo, I.; Fujita, K.; Kubo, A.; Nihei, K.; Ogura, T. Antibacterial activity of coriander volatile compounds against Salmonella choleraesuis. J. Agric. Food Chem. 2004, 52, 3329-3332.

8. Lal, A.A.; Kumar, T.; Murthy, P.B.; Pillai, K.S. Hypolipidemic effect of Coriandrum sativum L. in triton-induced hyperlipidemic rats. Indian J. Exp. Biol. 2004, 42, 909-912.

9. Satyanarayana, S.; Sushruta, K.; Sarma, G.S.; Srinivas, N.; Subba Raju, G.V. Antioxidant activity of the aqueous extracts of spicy food additives-evaluation and comparison with ascorbic acid in in-vitro systems. J. Herb. Pharmacother. 2004, 4, 1-10.

10. Jagtap, A.G.; Shirke, S.S.; Phadke, A.S. Effect of polyherbal formulation on experimental models of inflammatory bowel diseases. J. Ethnopharmacol. 2004, 90, 195-204.

11. Gray, A.M.; Flatt, P.R. Insulin-releasing and insulin-like activity of the traditional anti-diabetic plant Coriandrum sativum (coriander). Br. J. Nutr. 1999, 81, 203-209.

12. Al-Said, M.S.; Al-Khamis, K.I.; Islam, M.W.;Parmar, N.S.; Tariq, M.; Ageel, A.M. Post-coital antifertility activity of the seeds of Coriandrum sativum in rats. J. Ethnopharmacol. 1987, 21, 165-173.

13. Özbek, H., Aydın, H.İ.M.; Türközü, D. "Kişniş (Coriandrum sativum L.) uçucu yağ ekstresinin letal doz düzeyleri ile antienflamatuvar aktivitesinin araştırılması" [The Levels Of Lethal Dose And Anti-Inflammatory Effect Of Coriandrum Sativum L. Essential Oil Extract]. Ege Tip Dergisi 2006, 45, 163-167.

14. Abdel-Wahhab, M.A.; Nada, S.A.; Arbid, M.S. Ochratoxicosis: prevention of developmental toxicity by L- methionine in rats. J. Appl. Toxicol. 1999, 19, 7-12.

15. Kumar, A.; Kumar, R.; Kumar, N.; Nath, A.; Singh, J.K.; Ali M. Protective effect of Cuminum cyminum and Coriander sativum on profenofos induced liver toxicity. Int. J. Pharm \& Biol. Arc. 2011, 2, 1405-1409.

16. Pandey, A.; Bigoniya, P.; Raj, V.; Patel, K.K. Pharmacological screening of Coriandrum sativum Linn. for hepatoprotective activity. J. Pharm \& Bio Allied Sci. 2011; 3, 435-441.

17. Cioanca, O.;Hritcu, L.; Mihasan, M.; Hancianu, M. Cognitive-enhancing and antioxidant activities of inhaled coriander volatile oil in amyloid $\beta(1-42)$ rat model of Alzheimer's disease. Physiol Behav. 2013, 120, 193-202.

18. Samojlik, I.; Lakić, N.; Mimica-Dukić, N.; Đaković-Švajcer, K.; Božin, B. Antioxidant and Hepatoprotective Potential of Essential Oils of Coriander (Coriandrum sativum L.) and Caraway (Carum carvi L.) (Apiaceae). J. Agric. Food Chem. 2010, 58, 8848-8853.

(Received 24 August 2016; accepted o7 September 2016) 